\title{
Metamizole: Current Status of the Safety and Efficacy
}

\author{
Milijana N. Miljković ${ }^{1}$, Nemanja K. Rančić ${ }^{1}$, Radoje M. Simić \\ Dušica M. Stamenković ${ }^{3}$, Viktorija M. Dragojević-Simić ${ }^{1}$ \\ ${ }^{1}$ Centre for Clinical Pharmacology, Medical Faculty Military Medical Academy, University of \\ Defence, Belgrade, Serbia \\ ${ }^{2}$ Department for Plastic Surgery, Institute for Mother and Child Health Care of Serbia "Dr. \\ Vukan Cupic", Medical School, University of Belgrade, Belgrade, Serbia \\ ${ }^{3}$ Clinic for Anesthesiology and Critical Care, Medical Faculty Military Medical Academy, Uni- \\ versity of Defence, Belgrade, Serbia
}

\section{SUMMARY}

Metamizole is a nonsteroidal anti-inflammatory drug, with analgesic, antipyretic, spasmolytic, and weak anti-inflammatory properties. The analgesic effect of metamizole seems to be based on the inhibition of cyclooxygenase enzyme activity and stimulation of cannabinoid receptors. Its use is still controversial, mainly due to agranulocytosis, metamizole-induced serious adverse reaction. While in many countries it is withdrawn from the market, in some countries metamizole is available as a medication prescribed for strictly defined indications, while in the others like Mexico, Brazil and China it can be obtained as an Over-The-Counter drug. The most common adverse effects of metamizole are the skin and subcutaneous tissue disorders. Metamizole appears to be of similar efficacy to analgesics which are frequently used in the treatment of moderate to severe postoperative pain.

Keywords: metamizole, adverse drug reaction , agranulocytosis, pain, efficacy

\section{INTRODUCTION}

Metamizole is a nonsteroidal anti-inflammatory drug (NSAID), with analgesic, antipyretic, spasmolytic, and weak anti-inflammatory effects which belongs to the pyrazolones [1, 2]. It is a nonnarcotic analgesic with N02BB02 Anatomical Therapeutic Chemical code [3], which can be used orally and parenterally to prevent or treat pain of various origin and intensity, such as postoperative pain, acute injury pain, cancer and colic pain, as well as migraine [1-3].

\section{MATERIALS AND METHODS}

A general search strategy was developed to conduct the PubMed, Google Schoolar, Scopus, Web of Sciences, Embase, and SCIndex search to identify all studies describing the safety and efficiency of metamizole. The reference sections of identified original studies and review articles were examined to determine other potentially relevant original studies that were not identified by the primary search.

The following key words were used: metamizole, safety, adverse drug reaction, ad- 
verse event, agranulocytosis, pain, efficacy and NSAID. After that, the relevant papers are included in this review.

In our paper, we used the data obtained from EudraVigilance database (https:// www.ema.europa.eu/en/human-regulatory/ research-development/pharmacovigilance/ eudravigilance) and report of Medicines and Medical Devices Agency of Serbia (https:// www.alims.gov.rs/eng/).

The aim of our study was to show up current status of the metamizole safety and efficacy, as well as pharmacokinetics characteristics, indication for use and worldwide availability of metamizole.

\section{TOPIC}

\section{Mechanism of action}

Metamizole achieves effects by central and peripheral mechanisms [4], but the exact mechanism of its analgesic effect remains partially unclear [2]. The analgesic effect of metamizole seems to be based on the inhibition of cyclooxygenase (COX) enzyme activity, predominantly COX enzyme type 2 [1]. Also, this is the base for its antipyretic effects $[5,6]$. There is the an assumption that metamizole might be an inhibitor of the COX-3 isoenzyme, wich thereby reduces prostaglandin synthesis in the dorsal horn of the spinal cord [7]. It seems that metamizole also acts by stimulation of cannabinoid receptors; as naloxone blocks the analgesic effect of metamizole, the interaction with the endogenous opioid system is proposed as one of the possible mechanisms for its analgesic properties $[8,5]$. On the other hand, its weak anti-inflammatory activity, is possible due to the low affinity for COX in environments that are high in peroxide, such as inflamed tissues [9]. It has also been been reported that metamizole has a dose- dependent effect on platelet aggregation through the inhibition of TXA2 synthesis in platelets [10]. It also possesses a distinctive spasmolytic effect on the smooth muscles [10].

\section{Pharmacokinetics characteristics}

When it is administered orally, metamizole is rapidly hydrolysed to 4-methylaminoantipyrine (MAA), in gastric juice and this form is completely absorbed. The bioavailability of MAA was $85 \%$ for the tablets, $89 \%$ for the drops, $54 \%$ for the suppositories and $87 \%$ for the intramuscular injection [11].

Metamizole is metabolized in the liver, and flavin monoxygenases are involved in this process [12]. The 4 major metabolites of metamizole are MAA, 4-amino-antipyrine (AA), 4-acetyl-amino-antipyrine (AAA) and 4-formyl-amino-antipyrine (FAA) [11, 12]. None of them binds significantly to plasma proteins (57.6\% MAA, 47.9\% AA, 17.8\% FAA i $4.2 \%$ AAA). The volume of distribution after intravenouse use in healthy volunteers was 33 L. Plasma concentration half-life of metamizole is similar for MAA, AAA and FAA in both slow and rapid acetylators. It is possible that impaired hepatic metabolism largely contributes to the prolonged MAA elimination in the elderly. All major metabolites of metamizole passage into the cerebrospinal fluid [10, 11]. The transfer of metamizole metabolites to breast milk was determined. After the intravenous use, more than $90 \%$ of drug is eliminated by urine, and less than $10 \%$ is eliminated by feces. Forty-eight hours after drug administration, MAA and AA were undetectable and FAA and AAA were represented in negligible concentration [11].

\section{Clinical efficacy of metamizole}

There are many studies [13] which have compared analgesic efficacy of metamizole with other analgesics. Single dose metamizole appears to be of similar efficacy to analgesics which are frequently used in the treatment of moderate to severe postoperative pain [13].

Authors Derry et al., in their metaanalysis, compared analgesic effect of single dose of metamizole, administered per os or intravenously (i.v.), with other analgesics (referenca). They concluded that single $500 \mathrm{mg}$ dose of metamizole has similar efficacy as $400 \mathrm{mg}$ of ibuprofen, administered per os, while single $2.5 \mathrm{~g}$ dose of metamizole given i.v. is equivalent with tramadol, administered in doses of $100 \mathrm{mg}$, i.v. Metamizole is more effective than paracetamol given in dose of $1000 \mathrm{mg}$. [14].

Metamizole in dose of $1 \mathrm{~g}$ versus ibuprofen given in a single dose of $600 \mathrm{mg}$ showed similar therapeutic effect while $2 \mathrm{~g}$ of metamizole were superior to $600 \mathrm{mg}$ of ibuprofen administered in patients who had undergone extraction of the lower third molar [15].

Rawal et al. compared the efficacy of analgesics given in tablet formulations: trama- 
dol in dose of $100 \mathrm{mg}$ every $6 \mathrm{~h} ; 1 \mathrm{~g}$ of metamizole every $6 \mathrm{~h}$, and $1 \mathrm{~g}$ of paracetamol every 6 $\mathrm{h}$ in the patients who underwent ambulatory hand surgery with regional anesthesia.Tramadol was the most effective analgesic with the highest incidence of side effects. Metamizole and paracetamol provided good analgesia with a decreased incidence of side effects in comparison with tramadol [16].

Schug et al. researched the role of non-opioids for postoperative pain and concluded that repeated doses of metamizole, up to $4 \mathrm{~g}$ per $24 \mathrm{~h}$ were identical in efficacy to $4 \mathrm{~g}$ of paracetamol given i.v. after breast surgery [17].

Authors Ohnesorge et al. conducted a randomized, double-blind, placebo-controlled study, comparing the effects of paracetamol and metamizole, administered i.v. with a placebo in patients after mastectomy. These analgesics and a placebo were administered 20 minutes before the end of the surgical procedure, as well as 4,10 and $16 \mathrm{~h}$ after it. The intensity of post-operative pain in the metamizole-treated group and in the placebo-treated patients was similar, while in the paracetamoltreated group it was lower in the first postoperative hour. In the second postoperative hour, the intensity of the pain was lower than 2.5 (assesment has been done with numerical scale) in all groups. The authors concluded that paracetamol showed better efficacy in comparison with metamizole, and the repeated administration of metamizole in the form of short-term i.v. infusion was not effective for the treatment of postoperative pain after mastectomy [18]. The explanation could be found in the pharmacokinetic characteristics of metamizole and the route of administration. Namely, it is assumed that a short time i.v. infusion does not achieve sufficient concentration of the active metabolite MAA (2.5-7.5 times faster excretion of MAA was recorded after i.v. injection than after oral drug administration) [18].

\section{Metamizole use during pregnancy and in pe- diatric population}

In many countries (German, Spain, Brazil) metamizole is also availible for the use in pediatric population. In children, recommended doses are $15-20 \mathrm{mg} / \mathrm{kg}$, per dosis. Oral formulation of metamizole in doses of $500 \mathrm{mg} / \mathrm{ml}$, as infant drops, is availible in Brazil [19]. In Germany, it is present on the market as infant drops $(500 \mathrm{mg} / \mathrm{ml})$, for children aged up to 3 months and who weigh more than $5 \mathrm{~kg}$, as well as in tablets form for children older than 10 years [20]. In our country metamizole is subjected to marketing authorization for persons older than 18 years, while in Croatia it is assigned for older than 15 years $[2,21]$. Based on the research which is conducted by Fieler et al.one dose of metamizole used for postoperative pain treatment in 1177 children aged up to 6 years was characterized as safe and tolerable [22].

The findings about teratogenic potential of metamizole are insufficient. In one of the studies the rate of congenital abnormalities in the metamizole group did not differ significantly from the rate in the paracetamol group. In the other study the connection between metamizole and diafragmal defects, cardiovascular abnormalities and other defects was established, in comparison with the control group [23]. Due to the insufficient data regarding the use of this drug in pregnancy, a study was conducted and data was reported by 555 pregnant women, in 2009, in Brasil. That was the first prospective study analyzing the teratogenic effect of metamizole in Latin America and was of great importance since its outpatient use is widespread and unrestricted. The data were obtained directly from the pregnant women or from their medical records or the antenatal notes. Based on this research, data have been obtained suggesting that metamizole use during pregnancy does not present any teratogenic risk and is not associated with intrauterine death, preterm birth, or low birth weight [23].

Metamizole is not licenced for use during pregnancy and lactation in Serbia, while it is allowed for use during the second trimester of pregnancy, under medical supervision in Croatia [2, 21].

\section{Adverse reactions to metamizole}

The most serious adverse effect of metamizole is agranulocytosis, which was the reason for withdrawal of this drug in many countries. Agranulocytosis (neutrophil count of less than $\left.5 \times 10^{9} \mathrm{~L}^{-1}\right)$ is a hematologic syndrome of acute onset in which the number of circulating neutrophils decreases, leading to a markedly increased susceptibility to bacterial infection, serious local infection or sepsis. Typical signs of agranulocytosis are inflammation of the 
mucosa, sore throat, fever, increased erythrocyte sedimentation without or with only slight lymph node enlargement $[13,24]$. They can appear from several days to up to 3 months after introducing metamizole into therapy. The risk of agranulocytosis seems to increase with duration of use, and it disappears 10 day after the last dose [25]. In the other hand, published epidemiologic studies have indicated a relatively low excess risk associated with short-term use of metamizole. The risk of agranulocytosis related to long-term use is still insufficiently clearly estimated [26]. Due to the same reason, metamizole was withdrawn from use in 1970s in USA. It was established that metamizole has similar chemical structure as antipirine, which was already indentified as provocator of agranulocytosis. There was cross over alergic reaction between antipirin and metamizole and therefore it was assumed that incidence agranulocytosis caused by metamizole was the same as for antipirine, so it was considered that the risk was one per 120 treated patients, based on prejudice, published and unpublished series of cases.

The international epidemiological study of agranulocytosis and aplastic anemia, organized by the metamizole manufacturers, showed that the overall annual incidence of agranulocytosis was 4.4 cases per million users (6.2 including hospital cases), with an annual mortality rate of 0.4 per million users [27]. The other recent study has concluded that the use of metamizole is associated with an estimated risk of agranulocytosis accounted 0.56 cases per million users [1]. Moreover, extensive epidemiological investigations showed that short-term exposure to metamizole does not increase the risk of agranulocytosis. This risk is lower than risk for aplastic anemia related to the application of indometacine or diclofenac [8].

In addition, the incidence of metam- izole-induced agranulocytosis has varied geographically [13]. In some countries as Bulgaria, the risk of metamizole-induced agranulocytosis was astimated as very low ( 0.037 to $1 \mathrm{mil}$ lion persons), in Greece one case per 133,000466,000 treatments, while in others such as Sweden (approximately 1:31,000 metamizoletreated inpatients and 1:1400 metamizoletreated outpatients) and the USA (0.79-0.86\%, with a mortality rate of $0.57 \%$ ) the incidence was high $[13,28]$. Studies over the last few years from Spain, Switzerland, Germany, Poland and Latin America have pointed to the rarity of this serious adverse effect of metamizole therapy [28].

Metamizol causes agranulocytosis by immunological mechanisms, and specific human leukocyte antigen or HLA alleles may confer the risk $[8,28]$. Also it is believed that repeated intravenous injections of metamizole might be directly toxic for granulocyte precursors [8]. In imune-mediated agranulocytosis, the drug or a metabolite binds irreversible to the neutrophil membrane. In the toxic reaction, the drug directly damages the myeloid precursor cells [29].

Several factors may affected on mortality caused by agranulocytosis, such as the length of application, general condition of the patient, treatment with effective spectrum antibiotics and/or Granulocyte Colony Stimulating Factor or G-CSF [30]. Analgetics which also can induce agranulocytosis are indometacin, oksifenbutazon and fenilbutazon. All adverse reactions to pyrazolones are not dosedependent [31]. Also metamizol-induced hemolytic anemia and aplastic anemia have been reported [13].

It is interesting to note that the first bone marrow transplantation in the former Yugoslavia was performed in the patient with agranulocytosis as ADR of metamizole [32].

Based on the data from EudraV-

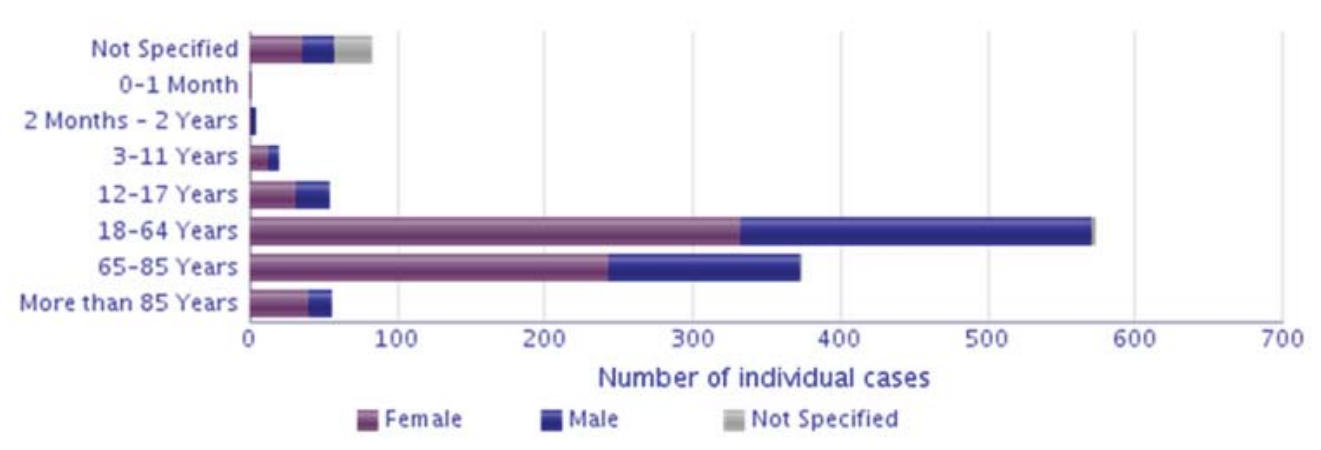

Figure 1. Distribution of individual cases of metamizole-induced agranulocytosis according by the patient age group 
Figure 2. Distribution of individual cases of metamizole-induced agranulocytosis according by their outcome

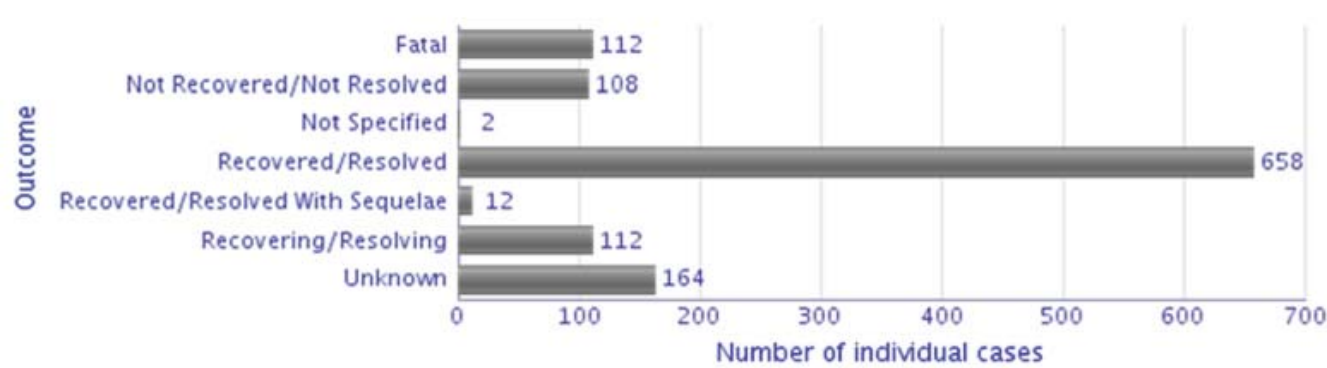

Figure 3. Number of individual cases of adverse effects of metamizole identified in EudraVigilance base in a period from November 2017 to October 2018

Figure 4. Distribution of metamizole adverse effects by the country in the European Economic Area reported up to October 2018

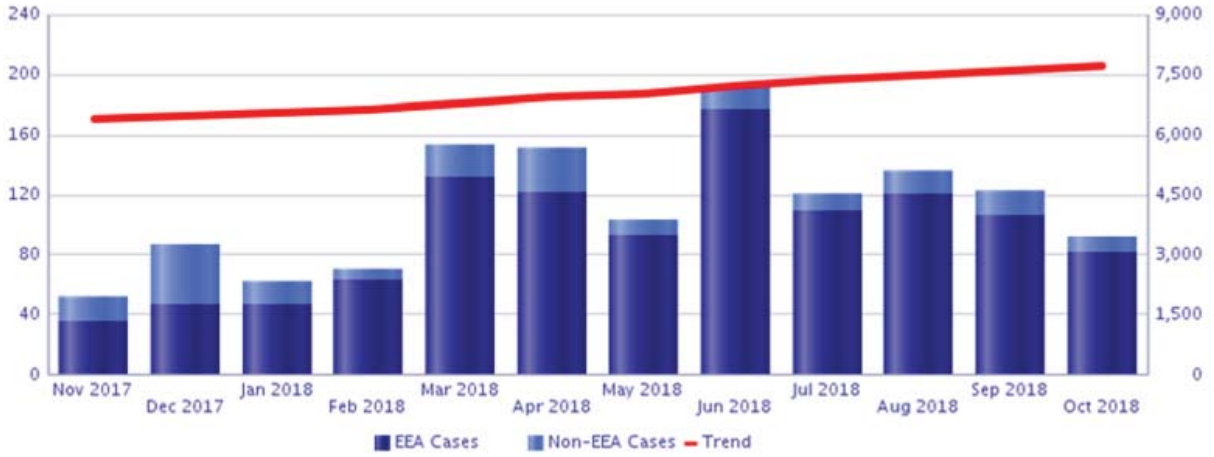

igilance base (https://bi.ema.europa.eu/analyticsSOAP/saw.dll?PortalPages), overall of 7711 adverse effects related to metamizole were reported so far (until October 2018).

Fifteen percent of these cases were reported as agranulocytosis. The most frequent appearance of agranulocytosis was registered in the age group from 18 to 64 years old (571 cases)

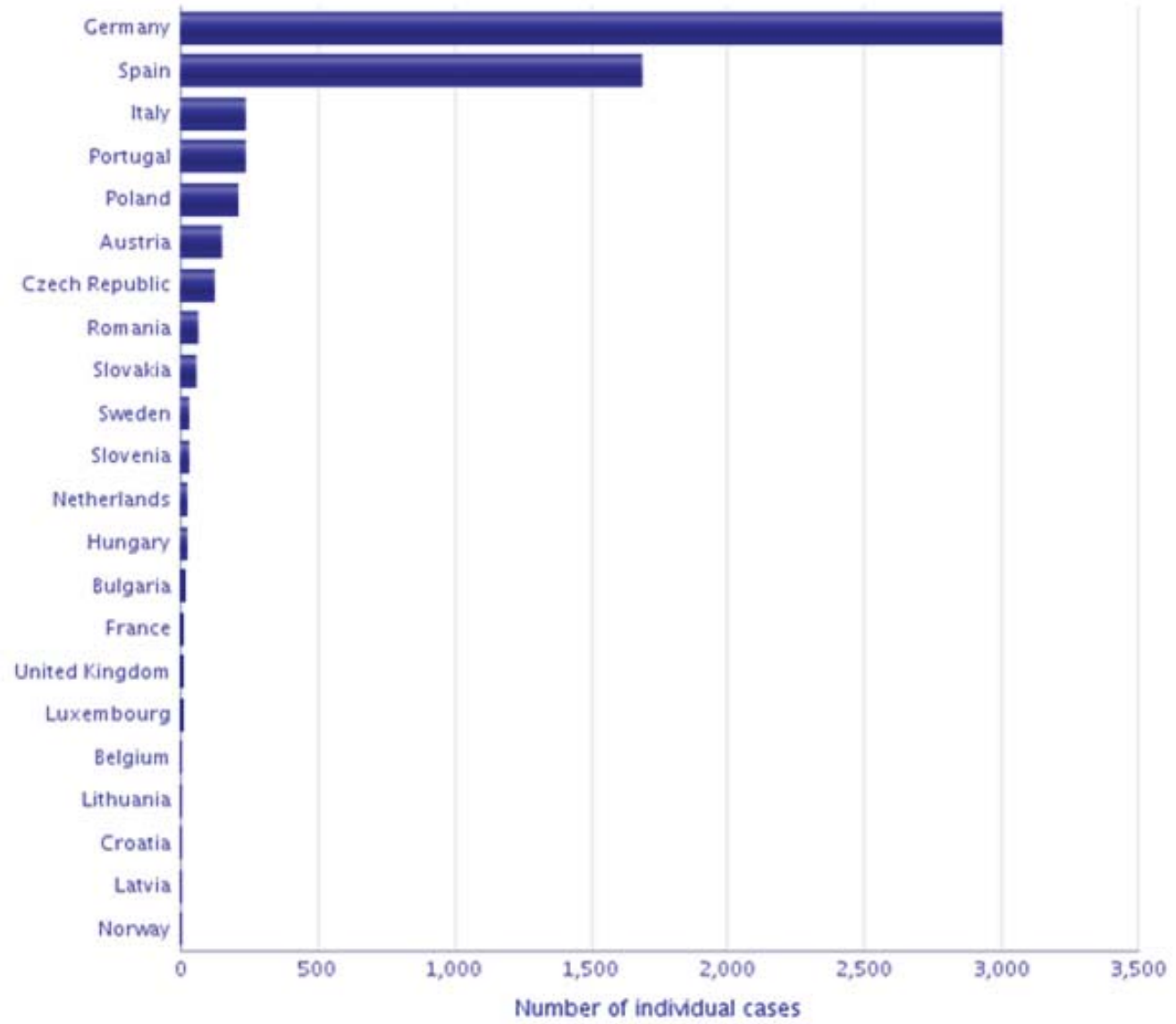




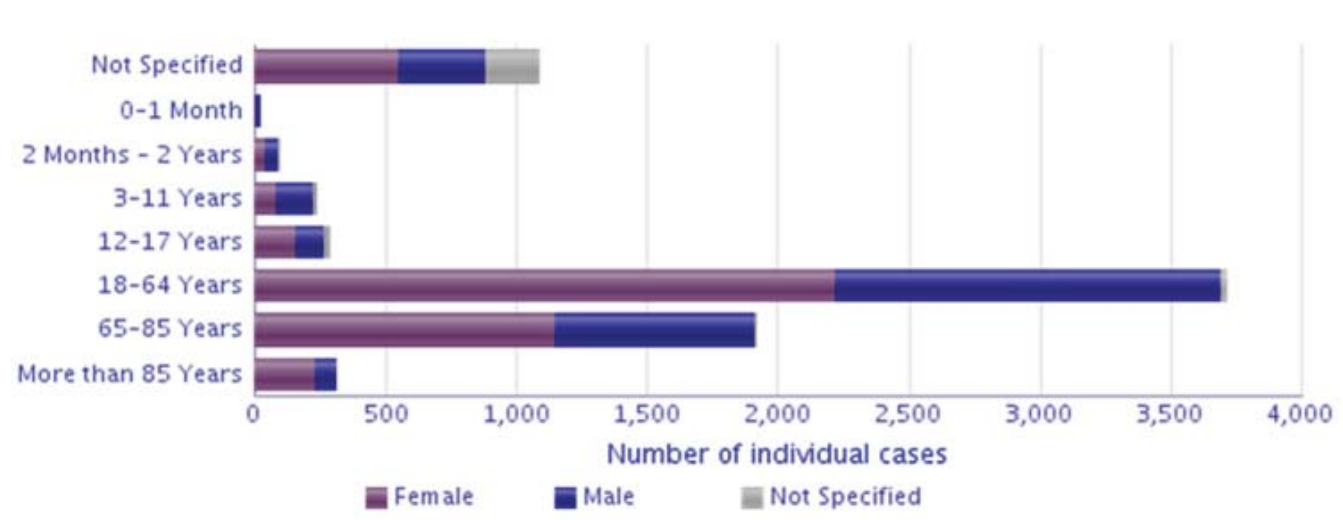

(Figure 1). That is the case with other adverse reactions to metamizole.

One hundered and twelve or $9.6 \%$ of 1162 cases of metamizole - induced agranulocytosis had fatal outcome (Figure 2). That means that $1.5 \%$ of overall adverse efects caused by metamizole had fatal outcome caused by agranulocytosis.

There is a trend (red line- cumulative number of metamizole adverse effects) of increasing reporting of adverse effects related to metamizole use in European countries during the last one-year (Figure 3).

Also there are differences between the countries from Europian Economic Area (EEA) and non-EEA. Significantly higher number of reported adverse effects was de- tected in EEA (Figure 3). The reason for that might be in different politics of prescribing metamizole in these countries as well as different habits of the medical doctors and pharmacists in reporting of adverse reactions to drugs. The countries in which metamizole is the most frequently used analgesic for postoperative pain treatment are Germany and Spain $[1,14]$ and therefore most of its adverse effects have been reported there. Thirty nine percent of the total number of reported adverse reactions to metamizole in EEA occurred in Germany while 22\% occurred in Spain (Figure 4).

Based on data from EudraVigilance, the difference between men and women in the frequency of reporting of overall metamizole induced adverse effects can be noticed i.e. they
Figure 5. All individual reported cases of metamizole adverse effects classified by the age and gender of the patients

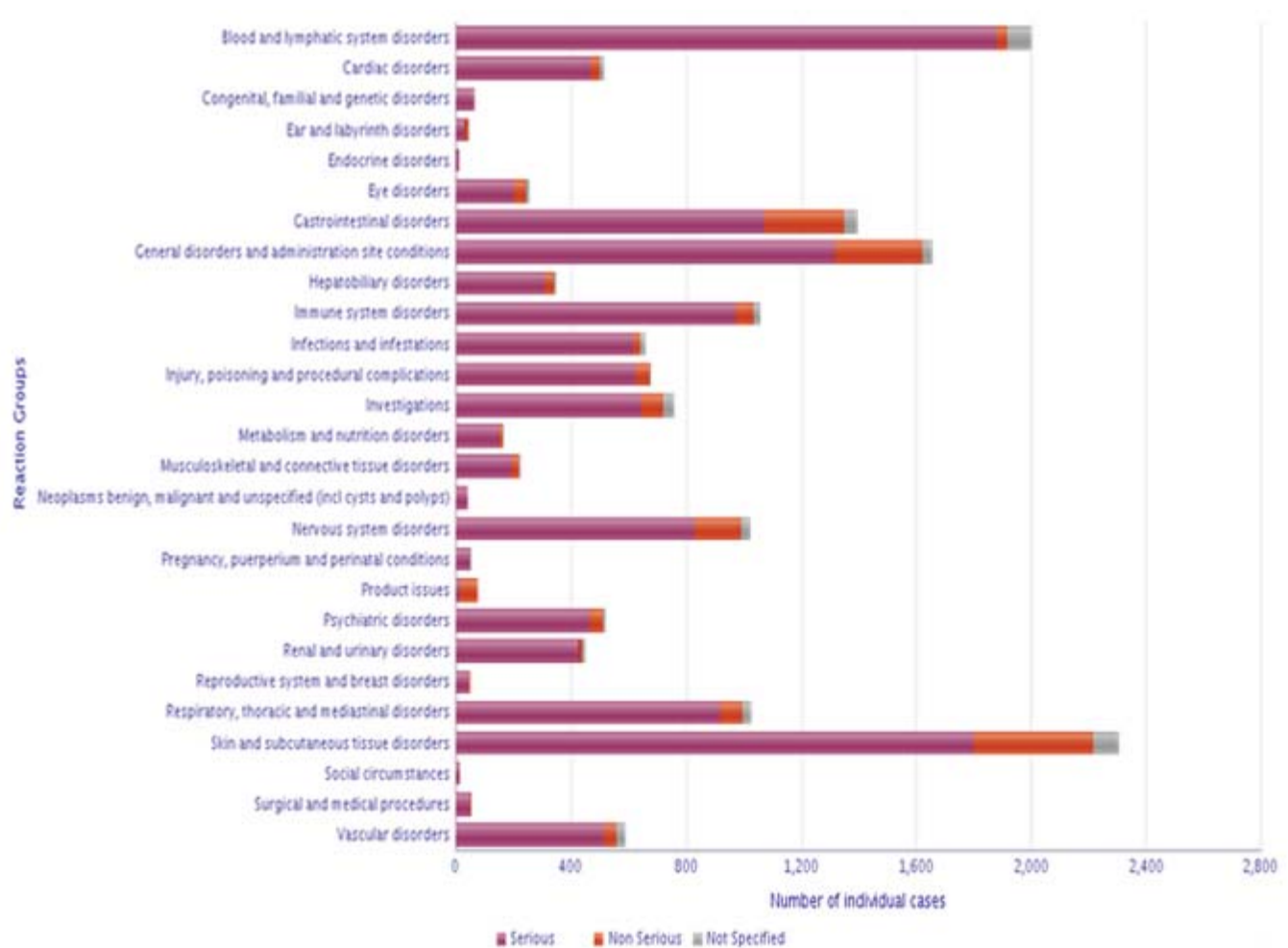

Figure 6. Structure of metamizole-related adverse reactions according to EudraVigillance [35] 
Figure 7. Outcomes of skin and subcutaneous tissue disorders caused by metamizole
Table 1. The overall number of adverse reactions to metamizole in a period from year 2013 to 2017 in Serbia

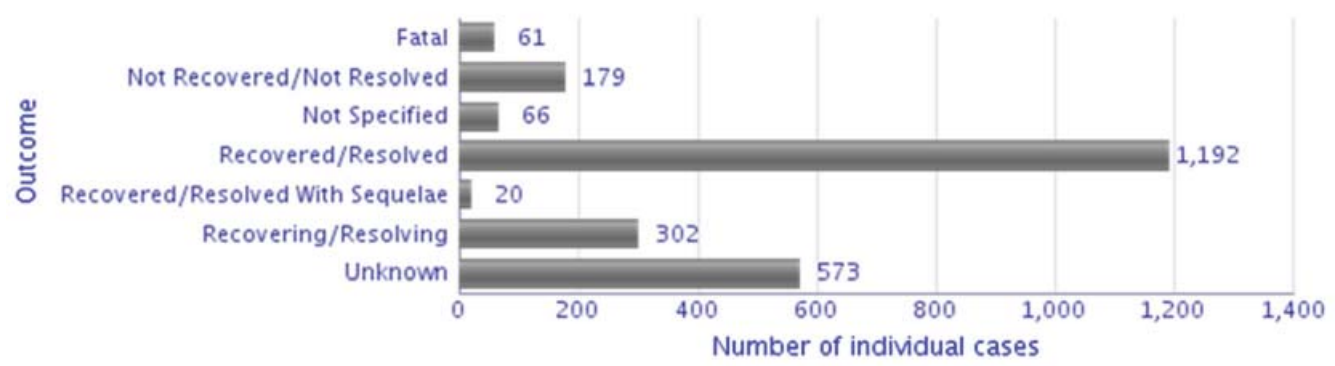

were more common in women than in men in all age groups (Figure 5). Also agranulocytosis is more common in women than in men (Figure 1).

The most common adverse reactions to metamizole, reported by Eudra Vigilance, were the skin and subcutaneous tissue disorders (30\%) (Figure 6). The serious adverse effects manifested like skin and subcutaneous tissue disorders are toxic epidermal necrolysis. Sixty one of 2308 cases had fatal outcome (Figure 7).

The most serious adverse reactions to metamizole occurred within blood and lymphatic tissue disorders. About 94\% of overall blood and lymphatic tissue disorders is estimated as serious (Figure 6).

Based on the data obtained from Medicines and Medical Devices Agency of Serbia (ALIMS) in the last five years, among 15 reported group of adverse reactions connected with metamizole skin and subcutaneous tissue disorders were present in 15 out of 50 reported cases (30\%). Almost $40 \%$ of the

patients with recorded adverse reactions to metamizole belongs to age group from 18 to 44 year old, followed by $32 \%$ of registered patients, who are from 65 to 74 year old. Female gender accounted for $60 \%$ of patients with recorded adverse reactions to metamizole. Adverse reactions to metamizole reported during five year period, in our country, are presented in Table 1.

The skin and subcutaneous disorders reported during metamizol were skin rash, urticaria, morbilliform, scarlatiniform, erythematous, bullous, purpuric, exudative or fixed drug eruption, pemphigus vulgaris and toxic epidermal necrolysis [13]. Skin rash induced by metamizole use was described as mild [13]. The anaphylactic reaction has been reported when metamizole was used both parenterally and orally, but parenteral administration was associated with a higher risk of developing these reactions [2]. Pyrazolone-induced urticaria or angio-oedema can be a manifestation of a pseudoallergic reaction, produced by the inhibition of COX [13]. The most serious

\begin{tabular}{l|r}
\hline \multicolumn{1}{c|}{ Adverse reaction } & Number (\%) \\
\hline Gender male/female & $2 / 13$ \\
\hline Median age & 36 (range 25-61) \\
\hline Median neutrophil count nadir (range) $\times 10^{9} / 1$ & 0.3 (range $0-0.5)$ \\
\hline Median duration of agranulocytosis days & $7(4-15)$ days \\
\hline recovery & $14(93.3 \%)$ \\
death & $1(6.6 \%)$ \\
\hline Asymptomatic neutropenia & $1(6.6 \%)$ \\
Isolated fever & $4(26.6 \%)$ \\
\hline Documented pneumonia & $4(26.6 \%)$ \\
\hline Nonsystemic infections, sore throats and acute tonsillitis & $5(33.3 \%)$ \\
\hline Normal & $4(26.6 \%)$ \\
\hline Hypoplasia of granulocytic cells & $5(33.3 \%)$ \\
Hyperplasia of granulocytic cells & $5(33.3 \%)$ \\
\hline Other abnormalities & $1(6.6 \%)$ \\
\hline History of adverse drug rection & $3(20.0 \%)$ \\
\hline Infection preceding acute agranulocytosis & $1(6.6 \%)$
\end{tabular}


life threatening cutaneous adverse effects are Stevens-Johnson's syndrome and toxic epidermal necrolysis (Lyell's syndrome).

Bronchospasm has also been described following administration of metamizole $[2,13]$. Allergic reactions to metamizole can even provoke asthma attack.

Since metamizole is a strong COX-1 inhibitor, one would expect adverse effects like gastric or duodenal ulcers. However, they were not reported more often than it would be expected in contrast to other non- selective NSAIDs. Metamizole has been shown relatively safe for the stomach and the duodenum [33].

Due to its mentioned mechanism of action it would also be expected that metamizole use is associated with kidney problems, but, based on the available data, it is relatively safe for kidney function [33].

There are hardly any reports in the literature of metamizole overdosage in humans. In the case of metamizole overdose nausea, vomiting, pain in the abdomen, kidney damage, hypotension, tachycardia, vertigo might occur [2]. Metamizole overdose was associated with mild, mainly gastrointestinal toxicity. After high dosis metamizole intake red color of urine, resulted from the excretion of a rubazonic acid was reported [11]. Treatment should include symptomatic and supportive measures.

\section{Availability of metamizole worldwide}

There is a different policy regarding metamizole usage among different countries which is related to adverse reactions to metamizole, especially due to agranulocytosis. In many of them, including the United States of America, the United Kingdom and Japan, it is withdrawn from the market; in some of them (Italy, Belgium, the Netherlands, Germany, Spain), it is available only as a prescription drug for strictly defined indications, while in Mexico, Brazil and China it can be obtained as an Over-TheCounter or OTC drug [1,29].

The indication for the metamizole use also seems to differ considerably. It was synthesized by the German company Hoechst AG under brandname "Novalgin" in 1920, and its mass production started in 1922 [10]. Therefore, it is still one of the most frequently prescribed analgesics in Germany. Indications for metamizole prescribing are: pain due to intestinal colic, postoperative pain, pain due to trauma, cancer pain and fever that is unresponsive to other measures [20].

In the Netherlands, it is only registered for i.v. use, and the indication for metamizole is short-term treatment of severe acute pain or high fever, if other drugs are contraindicated, or in case of high fever, when other methods have failed. These conditions are related to both adults and children [1]. In Spain, a survey of postoperative treatment in children showed that metamizole was one of the most frequently used analgesics [34]. Terefore, it is still used in some parts of Europe, as well as in South and Central America [1].

In Serbia, metamizole is a product licensed for short-term use in severe posttraumatic and postoperative pain, when therapy with other non-opioid analgesics is unsuccessful [2]. The available formulations are designed for oral, intravenous and intramuscular use. In Croatia, metamizole is marketingly authorized for the treatment of short-lasting severe pain of different origin (postoperative, posttraumatic, cancer pain, abdominal pain such as colic, and pain in other acute and chronic conditions), if other therapeutic interventions are insufficient [21].

\section{CONCLUSION}

Metamizole is still a stigmatized medication in various settings due to the reports of its relation to agranulocytosis. Despite this, its use is well-established in many countries where metamizole represents one of the most frequently used analgesics in postoperative pain management, both in adults and children, but also in other indications. Future randomized, controlled clinical trials should be organized with the aim of assessing its safety and efficacy, because the benefits of metamizole should be weighed against the risk of metamizole-induced adverse effects, especially in comparison with other NSAIDs. This is the only way of defining its place in the contemporary pharmacotherapy concerning pain management.

\section{REFERENCES}

1. Leeuw TG, Dirckx M, Gonzalez Candel A, Scoones GP, Huygen FJPM, de Wildt SN. The use of dipyrone (metamizol) as an analgesic in children: what is the evidence? A review. Paediatr Anaesth 2017; 27: 1193-201.

2. Medicines and Medical Devices Agency of Ser- 
bia. Search for human medicines- Metamizol-natrijum (2017). Available at: (https://www.alims. gov.rs/eng/medicinal-products/search-for-humanmedicines/?id=387870) Accessed date 03/ 27/2018

3. Medicines and Medical Devices Agency of Serbia. Marketing and consumption on medicines. Available at: http://www.alims.gov.rs/ciril/o-agenciji/publikacije/ Accessed date 03/27/2018

4. Levy M. Hypersensitivity to pyrazolones. Thorax 2000; 55(2): S72-4.

5. Jasiecka A, Ma'slanka T, Jaroszewski JJ. Pharmacological characteristics of metamizole. Pol J Vet Sci. 2014; 17:207-14.

6. Gaertner J, Stamer UM, Remi C, Voltz R, Bausewein C, Sabatowski R, et al. Metamizole/dipyrone for the relief of cancer pain: a systematic review and evidence-based recommendations for clinical practice. Palliat Med. 2017; 31:26-34

7. Chandrasekharan NV, Dai H, Roos K., Evanson NK, Tomsik J, Elton T, Simmons D. COX-3, a cyclooxygenase- 1 variant inhibited by acetaminophen and other analgesic/antipyretic drugs: Cloning, structure, and expression Proc Natl Acad Sci USA, 2002; 99 (21): 13926-13931.

8. Fursta DE, Ulrich RW, Varkey-Altamirano C. Nonsteroidal anti- Inflammatory drugs, antireumatics that modify the disease, non-opioid analgesic and medicines for treatment gout. In: Katzung B, Masters S, Trevor A, editors. Basic and Clinical Pharmacology. 11th ed Zagreb: Medicinska naklada 2011; p. 621-42.

9. Tatsuo MA, Carvalho WM, Silva CV, Miranda AE, Ferreira SH, Francischi JN. Analgesic and antiinflammatory effects of dipyrone in rat adjuvant arthritis model. Inflammation 1994; 18 (4): 399-405.

10. Nikolova I, Voynikov Y, Tencheva J, PetkovaV. Metamizole: A review profile of A well-known "forgotten" drug. Part I: Pharmaceutical and nonclinical profile. Biotechnol. \& Biotechnol. Eq. 2012; 26(6): 3329-3337.

11. Levy M, Zylber-Katz E, Rosenkranz B. Clinical pharmacokinetics of dipyrone and its metabolites. Clin Pharmacokinet. 1995;28(3):216-34.

12. Rendić S, Medić-Šarić M. Drug metabolism and selected xenobiotics. Zagreb: Medicinska naklada; 2013.

13. Nikolova I, Tencheva J, Petkova V, Voynikov Y. Metamizole: A review profile of A well-known "forgotten"drug. Part II: Clinical Profile. Biotechnol. \& Biotechnol Eq. 2013; 27(2): 3605-3619.

14. Derry Sh, Faura C, Edwards J, McQuay H, Moore A. Single dose dipyrone for acute postoperative pain. Cochrane Database Syst Rev. 2010; 9:CD003227. doi: 10.1002/14651858.CD003227.pub2

15. Planas ME, Gay-Escoda C, Bagan JV, Santamaria J, Penarrocha M, Donado M, Puerta JL, Garcia-
Magaz I, Ruiz J, Ortiz P. Oral metamizol (1 g and 2 g) versus ibuprofen and placebo in the treatment of lower third molar surgery pain: randomised doubleblind multi-centre study. Cooperative Study Group. Eur. J. Clin. Pharmacol. 1998; 53(6): 405-9.

16. Rawal N, Allvin R, Amilon A, Ohlsson T, Hallén J. Postoperative analgesia at home after ambulatory hand surgery: a controlled comparison of tramadol, metamizol, and paracetamol. Anesth. Analg. 2001; 92(2): 347-51.

17. Schug SA, Manopas A.Update on the role of non-opioids for postoperative pain treatment. Best Pract. Res. Clin. Anaesthesiol. 2007 ;21(1):15-30.

18. Ohnesorge $H$, Bein $B$, Hanss R, Francksen $H$, Mayer L, Scholz J, Tonner PH. Paracetamol versus metamizol in the treatment of postoperative pain after breast surgery: a randomized, controlled trial. Eur J Anaesthesiol. 2009;26(8):648-53.

19. Alves JG, Cardoso Neto FJ, Almeida CD, Almeida ND. Dipyrone and acetaminophen: correct dosing by parents? Sao Paulo Med J. 2007;125(1):57-9.

20. Analgin ${ }^{\circledR}$ tabletten. Arzneimittelinformationen. August 2017. 2017 by Rote Liste ${ }^{\oplus}$ Service $\mathrm{GmbH}$ Available at: https://online.roteliste.de/suche/ praep/12416/Analgin\%C2\%AE\%20Ampullen\%20\%20 Injektionsl\%C3\%B6sung Accessed date: 03/ 27/2018

21. Agency for Medicinal Products and Medical Devices of Croatia. Zagreb: HALMED. Available at: http://www.halmed.hr/Lijekovi/Baza-lijekova/ Analgin-500-mg-tablete/14101/ Accessed March 29, 2018

22. Fieler M, Eich C, Becke K, Badelt G, Leimkühler $\mathrm{K}$, Messroghli L, Boethig D, Sümpelmann R. Metamizole for postoperative pain therapy in 1177 children: A prospective, multicentre, observational, postauthorisation safety study. Eur J Anaesthesiol. 2015;32(12):839-43.

23. da Silva Dal Pizzol T, Schüler-Faccini L, Mengue SS, Fischer MI. Dipyrone use during pregnancy and adverse perinatal events. Arch Gynecol Obstet. 2009;279(3):293-7.

24. Miljković M, Rančić N, Dragojević-Simić $V$, Stamenković D. Metamizole for postoperative pain: PRO's and CON's. Proceedings 69-77.

25. Maj S, Lis Y. The incidence of metamizole sodium-induced agranulocytosis in Poland. J Int Med Res. 2002; 30:488-95.

26. Andrade S, Bartels D B, Lange R, Sandford L, Gurwitz J. Safety of metamizole: a systematic review of the literature. Journal of Clinical Pharmacy and Therapeutics. 2016; doi: 10.1111/jcpt.12422

27. Aronson JK. Meyler's Side Effects of drugs: The International Encyclopedia of Adverse Drug Reactions and Interactions. Fifteen edition. Amsterdam: Elselvier; 2006.p. 2268-2269.

28. Shah R. Metamizole (dipyrone)-induced agranu- 
locytosis: Does the risk vary according to ethnicity? J Clin Pharm Ther. 2018;1-5.

29. Vuik FE, Koehestanie P, Herbers AH, Terhaar Sive Droste JS. Chronic use of metamizole: not so safe after all? Neth J Med. 2017; 75:81-3.

30. Hedenmalm K, Spigset O. Agranulocytosis and other blood dyscrasias associated with dipyrone (metamizole). Eur J Clin Pharmacol. 2002;58(4):26574.

31. Grosser T, Smzth E, FityGerald G. Anti-Inflammatory, Antipyretic and Analgesic Agents; Pharmacotherapy of Gout. In: Brunton L, Chabner B, Knollmann B, editors. Goodman \& Gilman's The Pharmacological Basis of Therapeutics 12th ed. New York, NY: McGraw-HillCompany; 2011. p. 990.

32. Miljkovic M, Dragojevic-Simic V, Rancic N, Simic R, Pekez-Pavlisko T, Kovacevic A and Stamenkovic D (2018) Metamizole Utilization and Expenditure During 6-Year Period: Serbia vs. Croatia. Front. Public Health 2018; 6 (213). doi: 10.3389/ fpubh.2018.00213

33. Konijnenbelt-Peters J, Van der Heijden Ch, Ekhart C, Bos J, Bruhn J, Kramers C. Metamizole (Dipyrone) as an Alternative Agent in Postoperative Analgesia in Patients with Contraindications for Nonsteroidal Anti-Inflammatory Drugs. Pain Practice 2017; 17(3): 402-408.

34. Banos JE, Barajas C, Martın ML, et al. A survey of postoperative pain treatment in children of 3-14 years. Eur J Pain. 1999; 3:275-282.

35. Metamizole. EudraVigilance- European database of suspected adverse drug reactin reports, European Medicines Agency. Available at: http:// www.adrreports.eu/ Accessed date 10/22/2018 


\section{Metamizol: aktuelno stanje bezbednosti i efikasnosti}

Milijana N. Miljkovićn ${ }^{1}$ Nemanja K. Rančić ${ }^{1}$, Radoje M. Simić Dušica M. Stamenković ${ }^{3}$, Viktorija M. Dragojević-Simić ${ }^{1}$

${ }^{1}$ Centar za kliničku farmakologiju, Medicinski Fakultet Vojnomedicinske akademije Univerziteta Odbrane, Beograd, Srbija

${ }^{2}$ Klinika za dečiju hirurgiju, Institut za majku i dete "Dr. Vukan Čupić”, Medicinski fakultet, Univerzitet u Beogradu, Beograd, Srbija

${ }^{3}$ Klinika za anesteziologiju i intenzivno lečenje Vojnomedicinske akademije, Beograd, Srbija

\section{KRATAK SADRŽAJ}

Metamizol je nesteroidni antiinflamatorni lek koji poseduje analgetsko, antipiretsko, spazmolitičko i slabo antiinflamatorno dejstvo. Smatra se da je analgetsko dejstvo metamizola zasnovano na inhibiciji enzima ciklooksigenaza i stimulaciji kanabinoidnih receptora. Njegova upotreba je i dalje kontroverzna zbog agranulocitoze, ozbiljnog neželjenog efekta, čiji nastanak može biti izazvan primenom ovog leka. U mnogim zemljama je njegova upotreba zabranjena, u nekim se može propisivati pod strogim indikacijama, dok je u nekim zemljama, kao što su Meksiko, Brazil, Kina, u bezreceptnom režimu prodaje. Najčešći neželjeni efekti metamizola se ispoljavaju na koži i potkožnom tkivu. Smatra se da ima sličnu efikasnost sa analgeticima koji se često koriste u terapiji umerenog i jakog postoperativnog bola.

Ključne reči: metamizol, neželjeni efekti, agranulocitoza, bol, efikasnost 